\title{
Economic Efficiency of Different Agricultural Practices of "Panicum virgatum L. (switchgrass)" for Fodder Production
}

\author{
K. D. Giannoulis ${ }^{1}$, G. Vlontzos ${ }^{2}$, T. Karyotis ${ }^{3}$, D. Bartzialis ${ }^{1} \&$ N. G. Danalatos ${ }^{1}$ \\ ${ }^{1}$ University of Thessaly, Department of Agriculture, Crop Production \& Rural Environment, Laboratory of \\ Agronomy and Applied Crop Physiology, Fytokou Str., Volos, Greece \\ ${ }^{2}$ University of Thessaly, Department of Agriculture, Crop Production \& Rural Environment, Fytokou Str., Volos, \\ Greece \\ ${ }^{3}$ Institute for Soil Mapping and Classification, Larissa, Greece \\ Correspondence: K. D. Giannoulis, University of Thessaly, Department of Agriculture, Crop Production \& Rural \\ Environment, Laboratory of Agronomy and Applied Crop Physiology, Fytokou Str., Volos, Greece. Tel: \\ 30-242-1093-129. E-mail: kyriakos.giannoulis@gmail.com
}

\author{
Received: September 22, 2013 Accepted: October 8, 2013 Online Published: November 15, 2013 \\ doi:10.5539/jas.v5n12p132 URL: http://dx.doi.org/10.5539/jas.v5n12p132
}

\begin{abstract}
Switchgrass is a multipurpose perennial crop characterized by high yield (for fodder or raw material for pellet production) under low inputs conditions. This study sought to analyse the economic efficiency of different cultivating practices of switchgrass for hay or silage production. To assess the economic efficiency, three-year field experiments were established in two contrasting environments in central Greece (Palamas and Velestino) and contained two experimental factors: quantity of irrigation water (two levels: 0 and $250 \mathrm{~mm}$ ) and applied nitrogen fertilization (four levels: $0,80,160$ and $240 \mathrm{~kg} \mathrm{~N} \mathrm{ha}^{-1}$ ). Moreover, the costs of four different harvest methods (three different types of straw-bales for hay production and silage) were taken into account. The results demonstrated that production cost is largely depended on the harvesting practice. In addition, an attractive income of $1,745 € /$ ha (the higher one at Palamas site) for fodder production was found. The efficiency scores follow the same tendency at both sites, verifying that there is no necessity of high levels of nitrogen fertilization in order to improve switchgrass production efficiency. These data suggest that switchgrass is attractive as a fodder crop in regions with high precipitation or in areas with a moderately shallow groundwater table and should be seriously taken into consideration for future land use systems in Greece and more generally in the Mediterranean basin.
\end{abstract}

Keywords: switchgrass, economic efficiency, fodder, costs, profit, data development analysis

\section{Introduction}

The last two decades there is a worldwide interest on renewable energy sources and especially on biomass production. The use of bio-energy through biomass production from perennial crops may reduce the greenhouse gases emissions (Lychnaras \& Schneider, 2007). Moreover, it has been already worldwide accepted that the perennial ones produce high yields, while sinking large amounts of carbon into the soil (Tolbert et al., 2002; Liebig et al., 2005; Ma et al., 2000).

The perennial energy crops have received higher attention, due to their high productivity, and their low requirements (Keshwani, \& Cheng, 2009) in water (Tolbert \& Wright, 1998) and nutrients (P. Venturi \& G. Venturi, 2003). There are many environmental benefits associated with their cultivation; due to their perennial nature, where the cultivation practices like harrowing, plowing etc., take place only once at the establishment year, preventing soil degradation during the following subsequent years (Ma et al., 2000; McLaughlin et al., 1999; Vaughan et al., 1989; Kort et al., 1998; McKendry, 2002).

One of these perennial crops is switchgrass "Panicum virgatum L." which is known since the last century. Switchgrass is a plant with high adaptability in almost all soil types and is classified in two ecotypes: i) lowland and ii) upland, depending on latitude (Casler et al., 2007). Except of providing reliable energy, switchgrass also binds C in soil (Ma et al., 2000; Liebig et al. 2005; Skinner \& Adler, 2010).

Switchgrass is a perennial crop with height range from 1.5 to $2.5 \mathrm{~m}$ under favorable climatic conditions in Europe (Piscioneri et al., 2001; Lemus et al., 2002; Alexopoulou et al., 2008). Switchgrass develops a deep root 
system which exceeds a depth of $3 \mathrm{~m}$ (Liebig et al., 2005). The main growing factor is the air temperature (Madakadze et al., 1998) with the $10{ }^{\circ} \mathrm{C}$ being the basic growth temperature (Sanderson \& Wolf, 1995). The agricultural practices depend on the specific soil and climatic conditions of the area, which also define the variety choice (Fike et al., 2006).

Switchgrass is a promising cultivation due to its high value-added use, high production yield, low input requirements and a number of positive environmental impacts (Keshwani \& Cheng, 2009). There are many uses of switchgrass, such as grazing, protection from soil erosion, habitat for wildlife, but also as feed. It is rich in cellulose, thus making it attractive as a source for cellulosic ethanol (Schmer et al., 2006). Switchgrass is a nutritious and tasty food for most animals, especially for cattle (mainly used for grazing, but also for hay production) (Kansas State University, 2011). The quality of the feed is as similar as most grasses and mainly depends on crop maturity (Ball et al., 2011).

The choice of switchgrass both as fodder for cattle and as biomass for energy production could offer an attractive income for farmers and breeders, as the livestock farming is serving the backbone of Greek economy, but also each rural country like Greece. Flexibility in the use of switchgrass cultivation (due to its multipurpose uses) could also provide an incentive to adopt the production as a new rural-exploitation enterprise (Fox et al., 1999; Aravindhakshan et al., 2010; Guretzky et al., 2010).

The factors that influence (individually or through interaction) the economics of switchgrass cultivation are many (Sladden et al., 1991). Few of these factors are the establishment cost which defers from region to region, the annual input requirements (water and nutrients) (Smeets et al., 2009; Khanna et al., 2008), the soil-climatic conditions which affect the harvested yield (Monti et al., 2001) and the final product price (Fike et al., 2006; Eldersen et al., 2004).

Few data are reported about the economic performance of switchgrass in Europe and only few studies in North America are published, showing switchgrass having low cost per dry tone of biomass (Hallam et al., 2001; Downing \& Graham, 1996; Hanegraaf et al., 1998). There are reported different market prices but all of them are for dry biomass for solid biofuels (McLaughlin \& Kszos, 2005; Hallam et al., 2001; Fox et al., 1999) and not for fodder production.

Nowadays, switchgrass is grown in Greece on experimental basis for solid biofuels and fodder production. There are no data on switchgrass cultivation costs in Greece. Considering that any assessment of land use performance needs to quantify the biophysical production potential, followed by analysis of productivity at hierarchically lower levels of inputs and management practices. The objective of this paper is to report the production costs and to find out the harvesting system which gets switchgrass cultivation economically viable in Greece and in Mediterranean region for fodder production generaly.

\section{Method}

\subsection{Experimental Design}

A three-year $(2010,2011,2012)$ field experiments were conducted at two different soil-climatic environments in eastern and western Thessaly plain, central Greece as to be able to evaluate the economic efficiency of switchgrass cultivation for fodder production. The first experimental site is Palamas with soil characterized as a deep, calcareous ( $\mathrm{pH}=8.3$ ), sandy loam to loam (sand 37-45\%, loam 51-43\%, clay 12\%), with soil organic matter content of $0.9 \%$ at a depth of $40 \mathrm{~cm}$. The soil in Palamas site is characterized by a moderately shallow groundwater table, due to the surface irrigation networks (irrigation canals) of the territory. The second experiment carried out in Velestino with soil characterized as a calcareous $(\mathrm{pH}=8.1-8.3)$, clay loam to clay (sand 19-21\%, loam 39-41\%, clay 38-42\%), with soil organic matter content of $2.3-2.7 \%$ at a depth of $40 \mathrm{~cm}$. An underground pumping irrigation network is used in this territory (east Thessaly plain), which indicates a deep groundwater table.

The tested switchgrass variety was Alamo (lowland ecotype supplied from Colorado USA) at both sites, and the applied seed quantity was $7 \mathrm{~kg} \mathrm{ha}^{-1}$ using a modern cereal seeding machine, in a row-distance of $12.5 \mathrm{~cm}$. The experimental design was a randomized split-plot with four replications and eight plots per replication $(8 \times 4=32$ plots). Plot size was $48 \mathrm{~m}^{2}$ (6 $\mathrm{m}$ width $\times 8 \mathrm{~m}$ length).

\subsection{Economic Parameters}

The tested factors were two different irrigation levels ( $11=0 \mathrm{~mm}, \mathrm{I} 2=250 \mathrm{~mm})$, and four different $\mathrm{N}$-fertilization levels $\left(\mathrm{N} 1=0, \mathrm{~N} 2=80, \mathrm{~N} 3=160\right.$, and N4 $\left.=240 \mathrm{~kg} \mathrm{~N} \mathrm{ha}^{-1}\right)$. Moreover, the costs of four different harvesting methods were measured (3 different straw-bales and silage); while the effect of the selected area was also taken into consideration due to the different crop yield and the variation of costs. 
The economic costs of switchgrass were divided in two categories: i) Fixed costs, and ii) Variable costs. Fixed costs conclude depreciation, insurance for fodder production, invested capital interest, land rent and maintenance. Variable costs due to the perennial nature of switchrgrass cultivation were divided in two sub-categories: a) establishment costs, and b) annual cultivation costs. As establishment costs were calculated the plowing, cheelering, harrowing, sowing, herbicide application, seeds and labour costs for the preparation of the above practices ( $€$ /hour multiplied with the sum of the needed hours per hectare). These costs were divided for 10 years (switchgrass life cycle). Annual cultivation costs include irrigation, fertilization, labour for annual practices and harvesting costs which depend on the kind of practice ( $€ /$ bale for hay or $€ /$ ha for silage).

Furthmore, to calculate economic returns (per hectare) from switchgrass cultivation; existing market prices (from fodder crops prices-alfalfa hay $0.17-0.18 € \mathrm{~kg}^{-1}$ and silage $0.039-0.044 € \mathrm{~kg}^{-1}$, during 2011-12) were considered. The economic analysis is for the $2^{\text {nd }}$ and $3^{\text {rd }}$ growing years (2011 and 2012). Finally, sensitivity analysis was used to estimate the effect of product price to crop income benefits for the most viable case of switchgrass cultivation.

\subsection{Methods of Economic Assessment}

Efficiency and performance are a core concept of economics research. The relationship between them will be analyzed under the non-parametric method of Data Envelopment Analysis (DEA), based on a finite sample of observed production units, which uses a linear programming method and does not need to estimate a pre-established functional form. It follows the Farrell approach (1957) and was proposed in 1978 by Charnes, Cooper and Rhodes. The advantage of DEA is its flexibility and the possibility of using it for different scenario analysis.

In this paper the input-oriented envelopment model is applied assuming Constant Return to Scale (CRS) as well as Variable Returns to Scale (VRS). In CRS model the measure of global technical efficiency may be obtained by comparing large scale units with small scale units and vice versa. VRS model allows for variations in returns to scale. In this case an additional constraint is necessary that ensures the evaluation of pure technical efficiency regardless of issues of scale. Input oriented models try to maximize the proportional decrease in input variables, while output oriented ones will maximize the proportional increase in the output vector. The choice of one model or the other is based on the characteristics of the dataset analyzed. Every cultivating method is being assessed is named Decision Making Unit (DMU) when this methodology is being applied. The CRS DEA model assumes that the DMUs are operating at an optimal scale. This model permits a measure of global technical efficiency to be obtained without variations in returns to scale. In the real world, however, this optimal behaviour is often precluded by some factors such as imperfect competition, constraints, finance, etc. To take this circumstance into account, Banker, Charnes and Cooper (1984) have extended DEA to the case of variable returns to scale (VRS). This model distinguishes between pure technical efficiency and scale efficiency (SE), identifying if increasing, decreasing or constant returns to scale are present. The implementation of both methodologies provides the prospect of comparing efficiency scores of different cultivation practices under dissimilar levels of competition. Increased similarity of efficiency scores signifies high levels of competitiveness, while noteworthy differences provide considerable hints for low competitiveness globally.

The following equations are calculated in order to measure the technical efficiency of switchgrass cultivation:

\section{CRS Model}

$$
\min \theta-\varepsilon\left(\sum_{i=1}^{m} s_{i}^{-}+\sum_{r=1}^{S} s_{r}^{+}\right)
$$

Subject to

$$
\begin{gathered}
\sum_{j=1}^{n} \lambda_{j} \chi_{i j}+s_{i}^{-}=\theta x_{i o}, \mathrm{i}=1,2, \ldots, \mathrm{m} \\
\sum_{j=1}^{n} \lambda_{j} y_{r j}-s_{r}^{+}=y_{r o}, \mathrm{r}=1,2, \ldots, \mathrm{s}
\end{gathered}
$$




$$
\lambda_{j} \geq 0, \mathrm{j}=1,2, \ldots, \mathrm{n}
$$

VRS Model Add

$$
\sum_{j-1}^{n} \lambda_{j}=1
$$

where $\mathrm{j}$ is the number of observations of the DMUs. Each observation $\operatorname{DMU}_{j}(j=1,2, \ldots, n)$, uses $m$ inputs $x_{i j}(i=1$, $2, \ldots, m)$ to produce $s$ outputs $y_{r j}(r=1,2, \ldots, s)$. The efficient frontier is determined by these $n$ observations. There are two properties to ensure that a piecewise linear approximation has been developed to the efficient frontier and the area dominated by the frontier. $\sum_{j=1}^{n} \lambda_{j} \chi_{i j} \quad(i=1,2, \ldots, m)$ and $\sum_{j=1}^{n} \lambda_{j} y_{r j}$ $(r=1,2, \ldots, s)$ are possible inputs and outputs achievable by the $\mathrm{DMU}_{j}$, where $\lambda_{j}(j=1,2, \ldots, n)$ are nonnegative scalars that $\sum_{j=1}^{n} \lambda_{j}=1$. The same $y_{r j}$ can be obtained by using $\hat{x_{i j}}$, where $\hat{x_{i j}} \geq x_{i j}$ and the same $x_{i j}$ can be used to obtain $\hat{y_{i j}}$, where $\hat{y_{i j}} \geq y_{i j}$.

\section{Results}

\subsection{Yield}

Palamas site is characterized by a moderately shallow groundwater table, and is classified as Aquic Xerofluvent according to USDA (1975). It was observed that switchgrass reaches full production at the $2^{\text {nd }}$ year after establishment.

Table 1. Irrigation and fertilization effect on switchgrass harvest yield $\left(\mathrm{tha}^{-1}\right)$ for fodder production (silage)

\begin{tabular}{lcccc}
\hline & \multicolumn{2}{c}{ Palamas } & \multicolumn{2}{c}{ Velestino } \\
\cline { 2 - 5 } & $\mathbf{2}^{\text {nd }}$ Year & $\mathbf{3}^{\text {rd }}$ Year & $\mathbf{2}^{\text {nd }}$ Year & $\mathbf{3}^{\text {rd }}$ Year \\
\hline Irrigation levels & & & & \\
Rainfed & 48.6 & 51.1 & 15.4 & $20.94^{\mathrm{a}}$ \\
Irrigated $(250 \mathrm{~mm})$ & 50.6 & 50.8 & 20.4 & $29.56^{\mathrm{b}}$ \\
LSD $_{0.05}$ & $\mathrm{~ns}$ & $\mathrm{~ns}$ & $\mathrm{~ns}$ & 8.363 \\
Fertilization levels & $\left(\mathrm{kg} \mathrm{N} \mathrm{ha}{ }^{-1}\right)$ & & & \\
0 & 46.4 & 44.3 & 15.0 & 27.71 \\
80 & 45.1 & 53.5 & 19.4 & 23.53 \\
160 & 53.6 & 54.4 & 21.6 & 23.58 \\
240 & 52.8 & 51.8 & 15.6 & 25.78 \\
LSD $_{0.05}$ & $\mathrm{~ns}$ & $\mathrm{~ns}$ & $\mathrm{~ns}$ & $\mathrm{~ns}$ \\
\hline
\end{tabular}

*LSD: least significant difference at $\mathrm{P}<0.05,{ }^{* *}$ ns: not significant, ${ }^{* * *} \mathrm{a}$, b: Duncan criterion, $2^{\text {nd }}$ year: 2011 and $3^{\text {rd }}$ Year: 2012.

Table 1 shows the significant differences $(\mathrm{P}>0.05)$ that were found among irrigation levels and $\mathrm{N}$-fertilization levels in the case of silage harvesting method. It was found that switchgrass yield for silage production (65\% moisture content) was significantly affected $(\mathrm{P}<0.05)$ by irrigation level (Table 1$)$ only at Velestino site during the $3^{\text {rd }}$ year of establishment. Moreover, switchgrass yield for silage was not influenced by N-fertilization $(\mathrm{P}<0.05)$. The higher yield of $54.4 \mathrm{t} \mathrm{ha}^{-1}$ was recorded for the $\mathrm{N}$-fertilized plots with $160 \mathrm{~kg} \mathrm{~N}^{-1}$ at Palamas 
experimental site during the $3^{\text {rd }}$ year of establishment.

Harvesting method of bales (15\% moisture content) shown that there were not significant differences among irrigation and $\mathrm{N}$-fertilization levels (Table 2). It was found that switchgrass yield for hay production was higher $\left(21.9 \mathrm{t} \mathrm{ha}^{-1}\right)$ on fertilized plots with $160 \mathrm{~kg} \mathrm{~N} \mathrm{ha}^{-1}$ at Palamas experimental site during the $3^{\text {rd }}$ year of establishment.

Table 2. Irrigation and fertilization effect on switchgrass harvest yield $\left(\mathrm{t} \mathrm{ha}^{-1}\right)$ for fodder production (hay bale)

\begin{tabular}{lcccc}
\hline & \multicolumn{2}{c}{ Palamas } & \multicolumn{2}{c}{ Velestino } \\
\cline { 2 - 5 } & $\mathbf{2}^{\text {nd }}$ Year & $\mathbf{3}^{\text {rd }}$ Year & $\mathbf{2}^{\text {nd }}$ Year & $\mathbf{3}^{\text {rd }}$ Year \\
\hline Irrigation levels & & & & \\
Rainfed & 18.3 & 21.1 & 7.0 & 11.0 \\
Irrigated $(250 \mathrm{~mm})$ & 19.2 & 20.1 & 8.8 & 13.3 \\
LSD $_{0.05}$ & $\mathrm{~ns}$ & $\mathrm{~ns}$ & $\mathrm{~ns}$ & $\mathrm{~ns}$ \\
Fertilization levels & $\left(\mathrm{kg} \mathrm{N} \mathrm{ha}{ }^{-1}\right)$ & & & \\
0 & 18.1 & 18.0 & 6.5 & 12.9 \\
80 & 17.5 & 21.4 & 9.0 & 11.8 \\
160 & 20.0 & 21.9 & 9.4 & 11.3 \\
240 & 19.4 & 21.1 & 6.7 & 12.6 \\
$\mathrm{LSD}_{0.05}$ & $\mathrm{~ns}$ & $\mathrm{~ns}$ & $\mathrm{~ns}$ & $\mathrm{~ns}$ \\
\hline
\end{tabular}

*LSD: least significant difference at $\mathrm{P}<0.05$, **ns: not significant, $2^{\text {nd }}$ year: 2011 and $3^{\text {rd }}$ Year: 2012.

Table 3. Switchgrass cultivation costs

\begin{tabular}{ccc}
\hline \multirow{6}{*}{$/ \mathbf{h a}$} & Palamas & Velestino \\
\cline { 2 - 3 } Fixed Costs & 200 & \\
\hline Depreciation & 68 & 68 \\
Insurance & 267.4 & 267.4 \\
Invested Capital Interest & 700 & 700 \\
Land Rent & 6 & 6 \\
Maintenance & 1241.4 & 1241.4 \\
Total & & \\
Variable Costs & & \\
\hline Establishment costs & 90 & 70 \\
Plowing & 40 & 20 \\
Cheelering & 60 & 40 \\
Harrowing & 20 & 20 \\
Sowing Machine & 20 & 20 \\
Herbicide application & 462 & 462 \\
Seeds & 59.2 & 59.2 \\
Labour & 751.2 & 691.2 \\
Total & & \\
\hline Establishment* & 75.12 & 69.12
\end{tabular}

* Establishment costs are divided with 10 years which are the minimum years that switchgrass cultivation re-grows. 


\subsection{Production Costs}

Table 4. Switchgrass variation cultivation costs due to area and annual yield

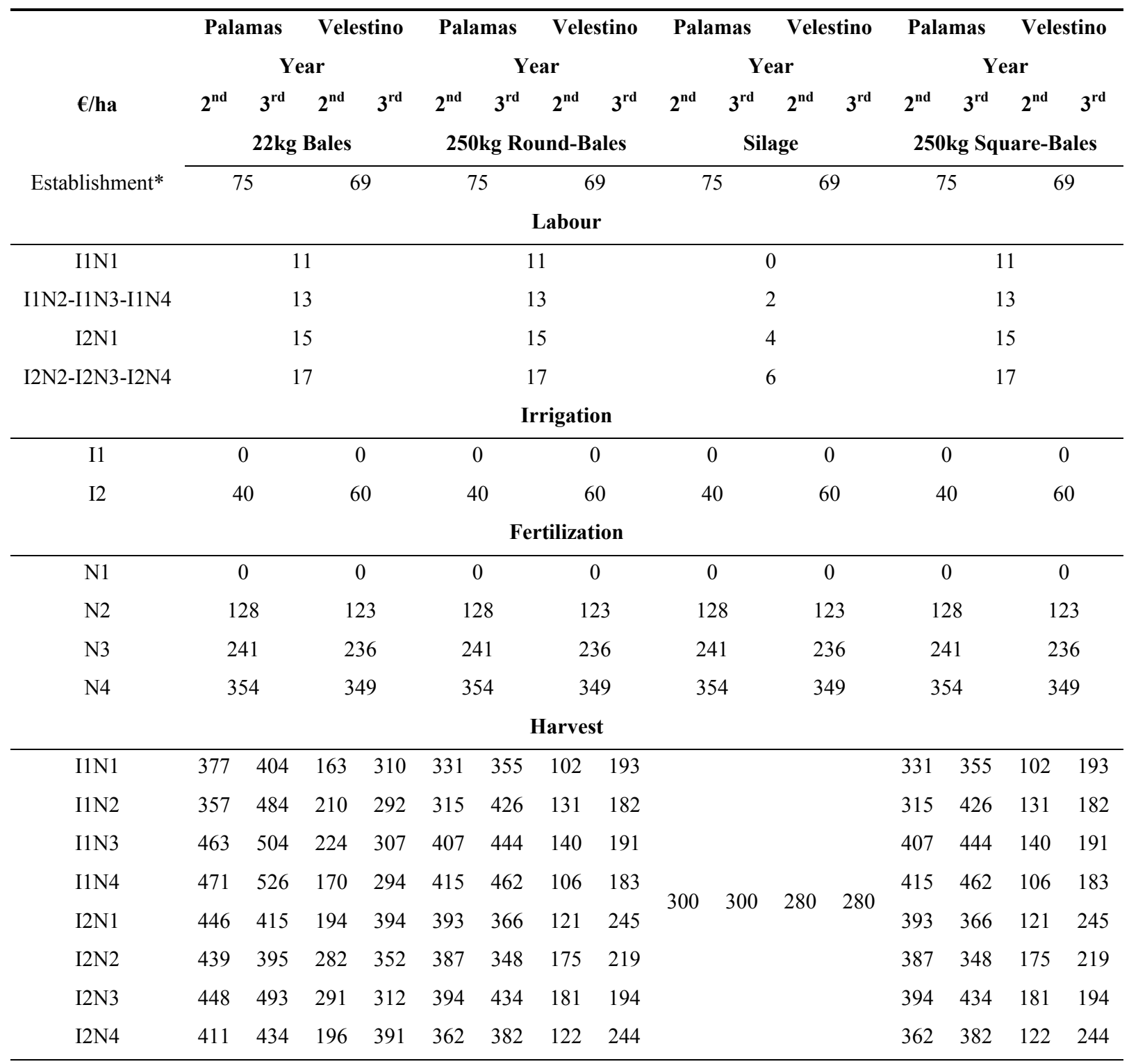

* Establishment costs are divided with 10 years which are the minimum years that switchgrass cultivation re-grows, Irrigation: I1-0 mm, I2-250 mm, N-fertilization: N1-0, N2-80, N3-160, N4-240 $\mathrm{kg} \mathrm{N} \mathrm{ha}^{-1}$.

Switchgrass cultivation costs are presented in Figure 1 and Tables 3, 4. Higher average production costs were reported in the case of small square bales of $22 \mathrm{~kg}$, during the $3^{\text {rd }}$ growing year in Palamas area. The required expenses for this case are $2,249 € \mathrm{ha}^{-1}$. On the other hand the case with the lower average production costs was the bales of $250 \mathrm{~kg}$ (round or square) during the $2^{\text {nd }}$ (2011) growing year in Velestino area; where the yield was the lower, and the required expenses are $1,473 € \mathrm{ha}^{-1}$.

Farmers' profit from switchgrass cultivation for hay or silage production is illustrated in Figure 2. It is clearly shown that farmers' profit is almost positive in every case of hay at both sites when switchgrass is in full production. At Velestino site during the $2^{\text {nd }}$ growing year (2011) farmer's profits are positive only for hay production in treatment of irrigated plots with $80 \mathrm{~kg} \mathrm{~N} \mathrm{ha}^{-1}$. The case of silage at Velestino site has negative values for farmer's income. 

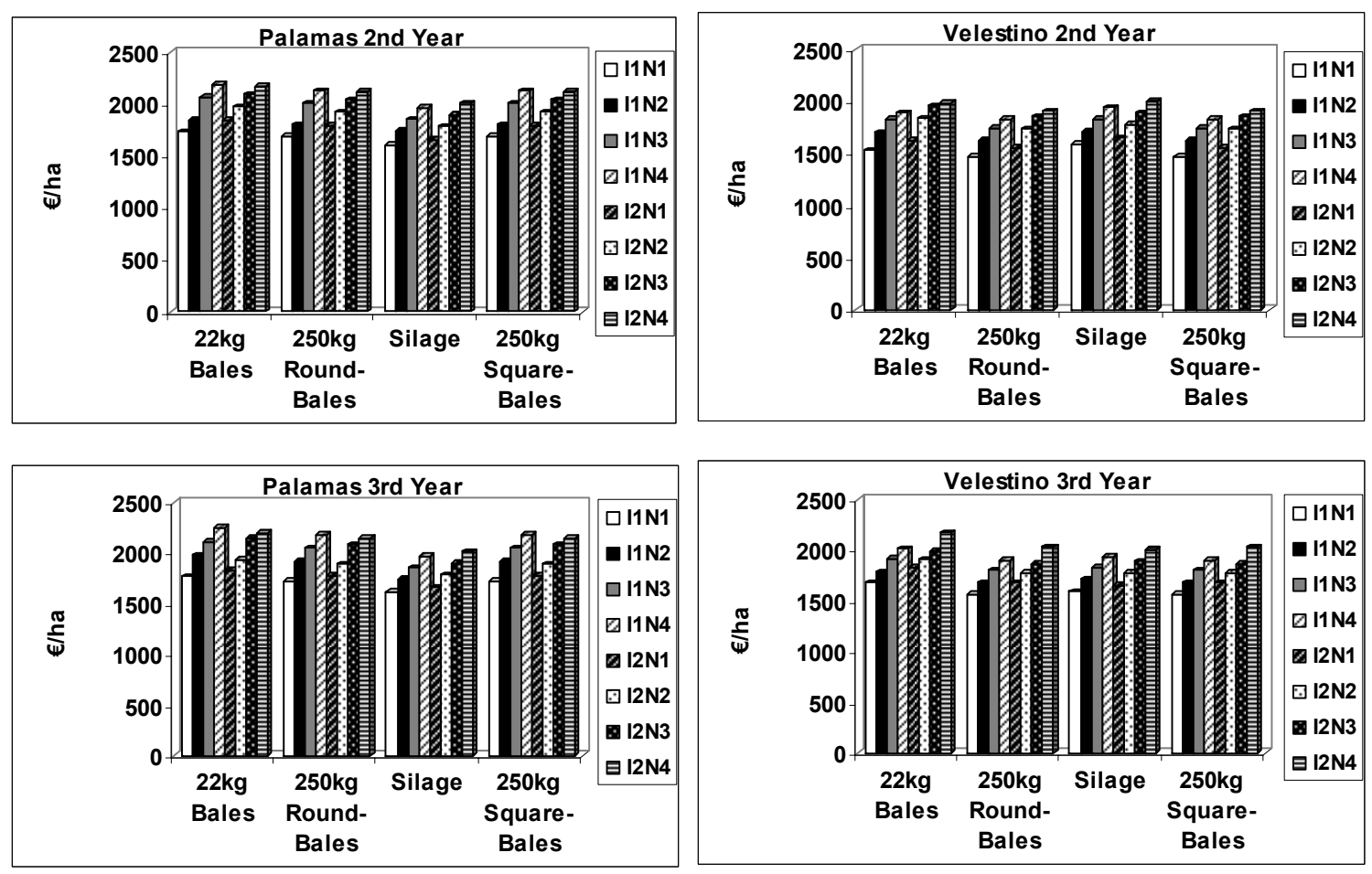

Figure 1. Switchgrass cultivating costs as observed at the study sites (Palamas and Velestino) during the $2^{\text {nd }}$ and $3^{\text {rd }}$ year of establishment as affected by 2 irrigation and $4 \mathrm{~N}$-fertilization levels under 4 different harvesting managements
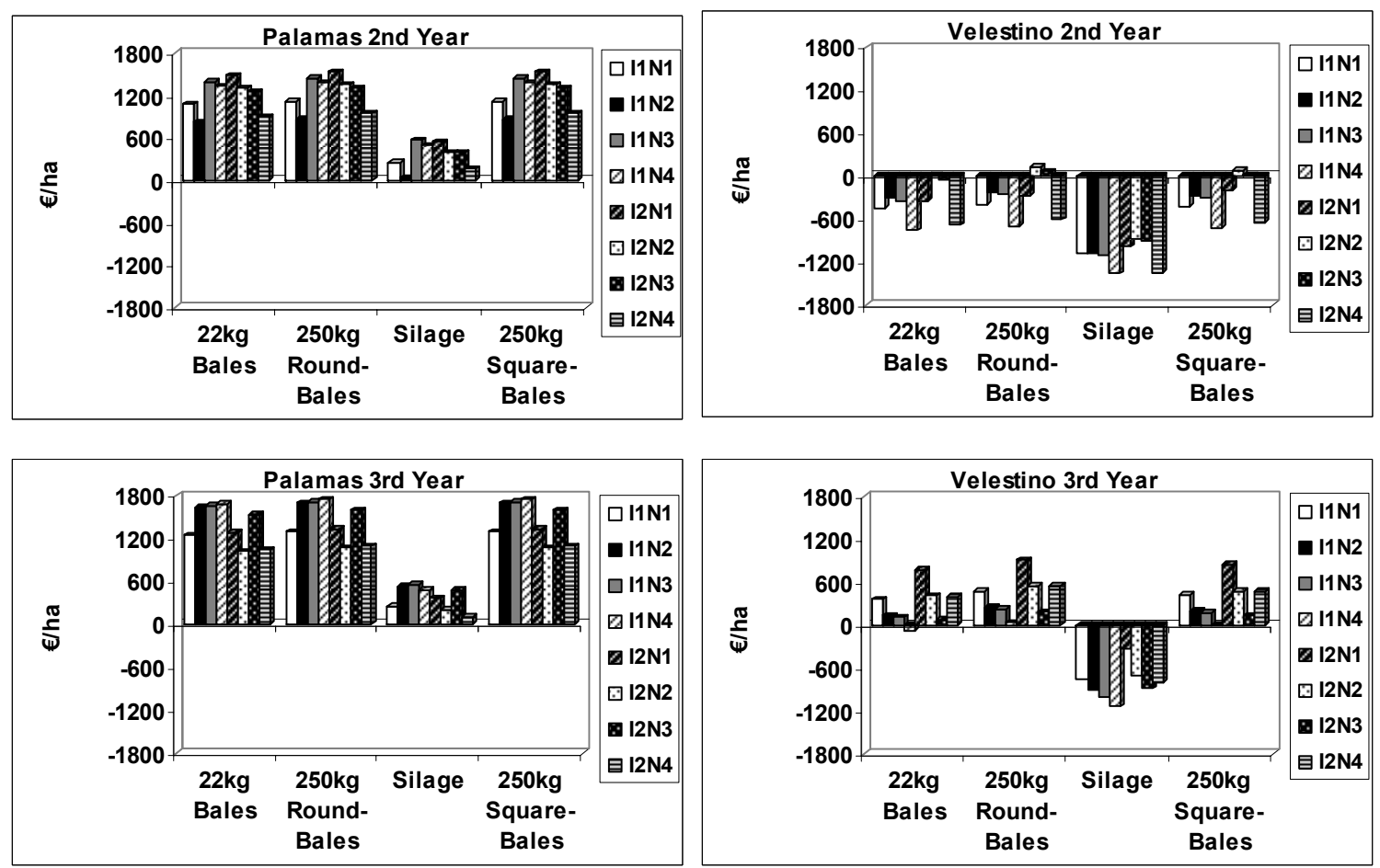

Figure 2. Farmer-profit from switchgrass cultivation as observed at the study sites (Palamas and Velestino) during the $2^{\text {nd }}$ and $3^{\text {rd }}$ year of establishment as affected by 2 irrigation and $4 \mathrm{~N}$-fertilization levels, under 4 different harvesting managements 
Silage can give an average profit of $350 € \mathrm{ha}^{-1}$ at Palamas area while at Velestino area this amount is negative. On the other hand, in case of big hay-bales (square or round), average farmers' profit increased up to 1,443 and $398 € \mathrm{ha}^{-1}$ at Palamas and Velestino, respectively.

Harvesting method of higher income is big hay bales at Palamas for non-irrigated and fertilized with 160 and $240 \mathrm{~kg} \mathrm{~N} \mathrm{ha}^{-1}$. These methods increase farmers' profit up to $1,745 € \mathrm{ha}^{-1}$. In this case, a reduction of about $45 \%$ on hay price is limited for switchgrass cultivation according to sensitivity analysis (Figure 3 ).

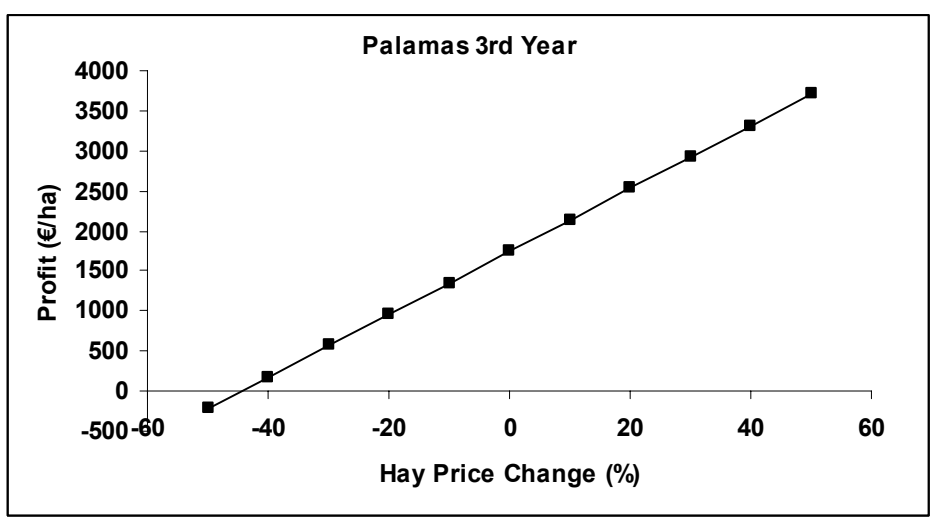

Figure 3. Effect of hay price change on farmer's profit in case of $250 \mathrm{~kg}$ bales

\subsection{Data Envelopment Analysis (DEA)}

As it has been already mentioned the production costs for different cultivating and harvesting methods were used as inputs. More specifically, the four inputs being used were the production costs when the switchgrass is being harvested by $250 \mathrm{~kg}$ round bale, $250 \mathrm{~kg}$ square bale, $22 \mathrm{~kg}$ small square bale, and silage. As outputs, were used the revenues being achieved for the four different cultivating and harvesting methods already mentioned. As DMUs, were used the 8 different combinations of irrigation and fertilization being applied in both Palama and Velestino site, having in total 16 DMUs. Two separate computations have been applied for the second and third year of the cultivation. The following table shows the efficiency scores for both the CRS and VRS methods

Table 6 shows the efficiency scores being achieved, when the two different DEA methods are being applied, with the CRS scores to be lower than the VRS ones. The most interesting issue is the significant decrease of efficiency scores when the nitrogen levels are being increased. In both cases of Palama and Velestino the efficiency scores follow the same tendency, verifying that there is no necessity of high levels of nitrogen fertilization in order switchgrass cultivation efficiency to be improved, as it shown in Table 8 .

Table 5. Descriptive Statistics

\begin{tabular}{lcl}
\hline \multicolumn{1}{c}{ VRS } & CRS \\
\hline \multirow{3}{*}{$\begin{array}{l}\mathbf{2}^{\text {nd }} \text { Year } \\
\text { Standard Deviation }\end{array}$} & 0.65999 & 0.59815 \\
Min & 0.197647 & 0.181266 \\
Max & 0.37805 & 0.37622 \\
& 1 & 1 \\
Mean & $\mathbf{3}^{\text {rd }}$ Year & \\
Standard Deviation & 0.210331 & 0.209881 \\
Min & 0.76329 & 0.64061 \\
Max & 0.40856 & 0.38063 \\
& 1 & 1 \\
\hline
\end{tabular}


Table 6. CRS and VRS DEA Results

\begin{tabular}{|c|c|c|c|}
\hline & & $\begin{array}{l}\text { Input-Oriented } \\
\text { VRS }\end{array}$ & $\begin{array}{l}\text { Input-Oriented } \\
\text { CRS }\end{array}$ \\
\hline $\begin{array}{l}\text { Cultivation } \\
\text { sites }\end{array}$ & $\begin{array}{l}\text { DMU } \\
\text { Name }\end{array}$ & Efficiency & Efficiency \\
\hline \multicolumn{4}{|c|}{ 2nd Year } \\
\hline PALAMAS & I1N1 & 1.00000 & 0.93849 \\
\hline PALAMAS & I1N2 & 0.78294 & 0.68023 \\
\hline PALAMAS & I1N3 & 0.58810 & 0.53307 \\
\hline PALAMAS & I1N4 & 0.53029 & 0.43935 \\
\hline PALAMAS & $\mathrm{I} 2 \mathrm{~N} 1$ & 1.00000 & 0.70396 \\
\hline PALAMAS & $\mathrm{I} 2 \mathrm{~N} 2$ & 0.69522 & 0.54854 \\
\hline PALAMAS & $\mathrm{I} 2 \mathrm{~N} 3$ & 0.57244 & 0.44902 \\
\hline PALAMAS & $\mathrm{I} 2 \mathrm{~N} 4$ & 0.46974 & 0.37995 \\
\hline VELESTINO & I1N1 & 1.00000 & 1.00000 \\
\hline VELESTINO & I1N2 & 0.72535 & 0.71304 \\
\hline VELESTINO & I1N3 & 0.66987 & 0.66838 \\
\hline VELESTINO & I1N4 & 0.56185 & 0.56011 \\
\hline VELESTINO & I2N1 & 0.61609 & 0.61422 \\
\hline VELESTINO & $\mathrm{I} 2 \mathrm{~N} 2$ & 0.47413 & 0.47277 \\
\hline VELESTINO & $\mathrm{I} 2 \mathrm{~N} 3$ & 0.49575 & 0.49308 \\
\hline VELESTINO & $\mathrm{I} 2 \mathrm{~N} 4$ & 0.37805 & 0.37622 \\
\hline \multicolumn{4}{|c|}{ 3rd Year } \\
\hline PALAMAS & I1N1 & 1.00000 & 0.93844 \\
\hline PALAMAS & I1N2 & 1.00000 & 0.68409 \\
\hline PALAMAS & I1N3 & 0.83122 & 0.53643 \\
\hline PALAMAS & I1N4 & 0.59987 & 0.43964 \\
\hline PALAMAS & $\mathrm{I} 2 \mathrm{~N} 1$ & 1.00000 & 0.70626 \\
\hline PALAMAS & $\mathrm{I} 2 \mathrm{~N} 2$ & 0.84921 & 0.55014 \\
\hline PALAMAS & $\mathrm{I} 2 \mathrm{~N} 3$ & 0.80242 & 0.45130 \\
\hline PALAMAS & $\mathrm{I} 2 \mathrm{~N} 4$ & 0.56348 & 0.38063 \\
\hline VELESTINO & I1N1 & 1.00000 & 1.00000 \\
\hline VELESTINO & I1N2 & 1.00000 & 1.00000 \\
\hline VELESTINO & I1N3 & 0.80147 & 0.80100 \\
\hline VELESTINO & I1N4 & 0.76154 & 0.75976 \\
\hline VELESTINO & $\mathrm{I} 2 \mathrm{~N} 1$ & 0.57974 & 0.57942 \\
\hline VELESTINO & $\mathrm{I} 2 \mathrm{~N} 2$ & 0.58335 & 0.58269 \\
\hline VELESTINO & $\mathrm{I} 2 \mathrm{~N} 3$ & 0.43176 & 0.43170 \\
\hline VELESTINO & $\mathrm{I} 2 \mathrm{~N} 4$ & 0.40856 & 0.40822 \\
\hline
\end{tabular}

Irrigation: I1-0mm, I2-250mm, N-fertilization: N1-0, N2-80, N3-160, N4-240 kg N ha ${ }^{-1}$. 
Table 7. Efficiency Scores Means for different irrigation applications

\begin{tabular}{lcl}
\hline & \multicolumn{1}{l}{ VRS } & CRS \\
\hline & $2^{\text {nd }}$ Year & \\
Palamas I1 & 0.725331 & 0.647784 \\
Palamas I2 & 0.684349 & 0.520366 \\
Velestino I1 & 0.739268 & 0.735381 \\
Velelstino I2 & 0.491005 & 0.489074 \\
& $3^{\text {rd }}$ Year & \\
Palamas I1 & 0.857772 & 0.649647 \\
Palamas I2 & 0.803778 & 0.522082 \\
Velestino I1 & 0.890752 & 0.890189 \\
Velelstino I2 & 0.500854 & 0.500507 \\
\hline
\end{tabular}

Irrigation: I1-0mm, I2-250mm.

Table 8. Efficiency Scores Means for different N-fertilization applications

\begin{tabular}{lll}
\hline & VRS & CRS \\
\hline 2nd Year & & \\
Palamas N1 & 1 & 0.821225 \\
Palamas N2 & 0.73908 & 0.614385 \\
Palamas N3 & 0.58027 & 0.491045 \\
Palamas N4 & 0.500015 & 0.40965 \\
Velestino N1 & 0.808045 & 0.80711 \\
Velestino N2 & 0.59974 & 0.592905 \\
Velestino N3 & 0.58281 & 0.58073 \\
Velestino N4 & 0.46995 & 0.468165 \\
3rd Year & & \\
Palamas N1 & 1 & 0.82235 \\
Palamas N2 & 0.924605 & 0.617115 \\
Palamas N3 & 0.81682 & 0.493865 \\
Palamas N4 & 0.581675 & 0.410135 \\
Velestino N1 & 0.78987 & 0.78971 \\
Velestino N2 & 0.791675 & 0.791345 \\
Velestino N3 & 0.616615 & 0.61635 \\
Velestino N4 & 0.58505 & 0.58399 \\
\hline C0
\end{tabular}

N-fertilization: N1-0, N2-80, N3-160, N4-240 $\mathrm{kg} \mathrm{N} \mathrm{ha}^{-1}$.

In both cases of Palamas and Velestino regions, the efficiency values followed the same trend, indicating that low levels of nitrogen fertilization enhance the economic competitiveness of switchgrass cultivation. Table 5 presents the descriptive statistics of the efficiency scores of both methodologies. It is obvious that there is significant improvement of efficiency scores for both methodologies, between the second and the third year of the cultivation.

In order to realise if there are significant changes on efficiency scores between the two different irrigation applications, in Table 7 the descriptive statistics of the efficiency scores per irrigation method per cultivation year are presented. It is clear enough in both CRS and VRS methodologies there is a non significant decrease of 
scores for Palamas. On the contrary, the decrease of scores of the Velestino site is quite high, signifying that switchgrass cultivation for fodder production in regions with high irrigation costs should be avoided.

\section{Discussion}

Switchgrass is a perennial crop with high recorded yields (Lemus et al., 2002; Boyer et al., 2013). In this study it was expected that higher yields for hay production but also for silage $(65 \%$ moisture $)$ would be recorded at Palamas site due to the moderately shallow groundwater table from the territory. Therefore, it can be concluded that switchgrass cultivation can produce high yields under none or limited irrigated conditions only in soils as above or in regions of high precipitation.

Switchgrass as a perennial crop has increased establishment costs mostly depended on high seed price. This cost is not great if it will distribute to the crop life cycle. Therefore as it is shown, production costs are largely depended by harvesting practice. Hay-bales costs depend by biomass production. The costs of a small bale ( 22 $\mathrm{kg}$ ) range from $0.5-0.6 € / \mathrm{bale}$ and $4.25-5 € / \mathrm{bale}$ for the big bales $(250 \mathrm{~kg})$. Therefore the case of the small bales have an increased harvesting cost of $3 €$ ton $^{-1}$.

Moreover, due to the fixed harvesting costs $\left(280-300 € \mathrm{ha}^{-1}\right)$, silage case is not viable for low yield productions like Velestino, in contrast to hay production which depends on final yield ( $€ /$ bale). The harvesting practice of silage seems to be positive only for territories with a present moderately shallow groundwater table or areas of high precipitation where switchgrass cultivation scores high yields.

Switchgrass seems to be a promising alternative perennial crop for fodder production which could lead to an income of $1,745 € /$ ha. This profit is similar to alfalfa crop $(1,700-1,900 € /$ ha) (Lony et al., 2008) but the advantage of switchgrass cultivation is that harvest period is once per year incontrast to alfalfa which has 4-5 harvests per year. Therefore, except the economical adavantges switcgrass has also environmental advantages due to less use of farming equipmnet.

Data Envelopment Analysis (DEA) showed that switchgrass cultivation does not require high amounts of nitrogen fertilization to increase its productivity. Similar attempts have as only outcome the decrease of efficiency and therefore should be avoid. Additionally, it is proved that higher efficiency can be achieved in areas with shallow moderate ground water table. The combination of these two findings is very important for both financial and environmental reasons. The adoption of this cultivation leads to satisfactory farmer income as well as low nitrogen inputs lead to satisfactory environmental protection of agricultural landscape.

In conclusion, switchgrass is a promising alternative perennial crop for fodder production, characterized by high biomass yield and an attractive income for farmers. It can be argued that switchgrass can exploit less fertile soils. Moreover, this crop has the advantage that can be also used for solid bio-fuel (pellets, briquettes) production and thus its introduction into future land use systems in Greece and Mediterranean basin more generally, should be seriously taken into consideration.

\section{References}

Alexopoulou, E., Sharma, N., Papatheohari, Y., Christou, M., Piscioneri, I., Panoutsou, C., \& Pignatelli, V. (2008). Biomass yields for upland and lowland switchgrass varieties grown in the Mediterranean region. Biomass and Bioenergy, 32(10), 926-933. http://dx.doi.org/10.1016/j.biombioe.2008.01.015

Aravindhakshan, S. C., Epplin, F. M., \& Taliaferro, C. M. (2011). Economics of switchgrass and miscanthus relative to coal as feedstock for generating electricity. Biomass Bioenergy, 34(9), 1375-1383. http://dx.doi.org/10.1016/j.biombioe.2010.04.017

Ball, D. M., Collins, M, Lacefield, G. D., Martin, N. P., Mertens, D. A., Olson, K. E., ... Wolf, M. W. (2001). Understanding forage quality. Park Ridge, Illinois: American Farm Bureau Federation Publication 1-01.

Banker, R. D., Charnes, A., \& Cooper, W. W. (1984). Some Models for Estimating Technical and Scale Efficiencies in Data Envelopment Analysis. Management Science, 30(9), 1078-1092.

Boyer, C. N., Roberts, R. K., English, B. C., Tyler, D. D., Larson, J., \& Mooney, D. F. (2013). Effects of soil type and landscape on yield and profit maximizing nitrogen rates for switchgrass production. Biomass Bioenergy, 48, 33-42. http://dx.doi.org/10.1016/j.biombioe.2012.11.004

Casler, M. D., Vogel, K. P., Taliaferro, C. M., Ehlke, N. J., Berdahl, J. D., Brummer, E. C., ... Mitchell, R. B. (2007). Latitudinal and longitudinal adaptation of switchgrass populations. Crop Science, 47(6), 2249-2260.

Charnes, A., Cooper, W., \& Rhodes, E. (1978). Measuring the Efficiency of Decision Making Units. European Journal of Operational Research, 6, 429-444. http://dx.doi.org/10.1016/0377-2217(78)90138-8 
Downing, M., \& Graham, R. L. (1996). The potential supply and cost of biomass from energy crops in the Tennessee valley authority region. Biomass and Bioenergy, 11(4), 283-303. http://dx.doi.org/10.1016/0961-9534(96)00004-9

Eldersen, H., Cristian, D., Bassam, N., Sauerbeck, G., Alexopoulou, E., Sharma, N., \& Piscioneri, I. (2004). A management guide for planting and production switchgrass as a biomass crop in Europe. 2nd Conference on Biomass for Energy Industry and Climate Protection, 10-14 May, Rome Italy.

Farrell, M. J. (1957). The measurement of productive efficiency. Journal of the Royal Statistical Society. Series A (General), 120(3), 253-290.

Fike, J. H., David, P. J., Wolf, D. D., Balasko, J. A., Green, J. T., Rasnake, M., \& Reynolds, J. H. (2006). Long-term yield potential of switchgrass for biofuel systems. Biomass and Bioenergy, 30(3), 198-206. http://dx.doi.org/10.1016/j.biombioe.2005.10.006

Fox, G., Girouard, P., \& Syaukat, Y. (1999). An economic analysis of the financial viability of switchgrass as a raw material for pulp production in eastern Ontario. Biomass and Bioenergy, 16(1), 1-12. http://dx.doi.org/10.1016/S0961-9534(98)00063-4

Guretzky, J. A., Biermacher, J. T., Cook, B. J., Kering, M. K., \& Mosali, J. (2010). Switchgrass for forage and bioenergy: harvest and nitrogen rate effects on biomass yields and nutrient composition. Plant Soil, 339(1-2), 69-81.

Hallam, A., Anderson, I. C., \& Buxton, D. R. (2001). Comparative economic analysis of perennial, annual, and intercrops for biomass production. Biomass and Bioenergy, 21(6), 407-424. http://dx.doi.org/10.1016/S0961-9534(01)00051-4

Hanegraaf, M. C., Biewinga, E. E., \& Van Der Bijl, G. (1998). Assessing the economical and ecological sustainability of energy crops. Biomass and Bioenergy, 15(4-5), 345-355. http://dx.doi.org/10.1016/S0961-9534(98)00042-7

Hitchcock, A. S. (1935). Manual of the grasses of the United States. USDA, Washington.

Kansas State University Agricultural Experiment Station and Cooperative Extension Service. (2011). Switchgrass Production Handbook. Kansas. J. Holman et al. (Eds). November 2011. Retrieved from http://www.ksre.ksu.edu/

Keshwani, D. R., \& Cheng, J. J. (2009). Switchgrass for bioethanol and other value-added applications: A review. Bioresource Technology, 100(4), 1515-1523. http://dx.doi.org/10.1016/j.biortech.2008.09.035

Khanna, M., Dhungana, B., \& Clifton-Brown, J. (2008). Costs of producing miscanthus and switchgrass for bioenergy in Illinois. Biomass and Bioenergy, 32(6), 482-493. http://dx.doi.org/10.1016/j.biombioe.2007.11.003

Kort, J., Collins, M., \& Ditsch, D. (1998). A review of soil erosion potential associated with biomass crops. Biomass and Bioenergy, 14(4), 351-359. http://dx.doi.org/10.1016/S0961-9534(97)10071-X

Lemus, R., Brummer, E. C., Moore, K. J., Molstad, N. E., Burras, C. L., \& Barker, M. F. (2002). Biomass yield and quality of 20 switchgrass populations in southern Iowa, USA. Biomass and Bioenergy, 23(6), 433-442. http://dx.doi.org/10.1016/S0961-9534(02)00073-9

Liebig, M. A., Johnson, H. A., Hanson, J. D., \& Frank, A. B. (2005). Soil carbon under switchgrass stands and $\begin{array}{lllll}\text { cultivated cropland. Biomass and Bioenergy, 28(4), 347-354. } & \text {. }\end{array}$ http://dx.doi.org/10.1016/j.biombioe.2004.11.004

Lony, R. F., Schmierer, J. L., Klonsky, K. M., \& Livingston, P. (2008). Sample costs to establish and produce Alfalfa hay. Univerity of California. Cooperative extension. Retrieved from http://coststudies.ucdavis.edu/files/AlfalfaSV08.pdf

Lychnaras, V., \& Schneider, U. A. (2007). Dynamic Economic Analysis of Perennial Energy Crops - Effects of the CAP Reform on Biomass Supply in Greece. FNU-132, Hamburg University and Centre for Marine and Atmospheric Science, Hamburg.

Ma, Z., Wood, C. W., \& Bransby, D. I. (2000). Carbon dynamics subsequent to establishment of switchgrass. Biomass and Bioenergy, 18(2), 93-104. http://dx.doi.org/10.1016/S0961-9534(99)00077-X

Ma, Z., Wood, C. W., \& Bransby, D. I. (2000). Soil management impacts on soil carbon sequestration by switchgrass. Biomass Bioenergy, 18(6), 469-477. http://dx.doi.org/10.1016/S0961-9534(00)00013-1 
Madakadze, I., Coulman, B. E., Stewart, K., Peterson, P., Samson, R., \& Smith, D. L. (1998). Phenology and tiller characteristics of big bluestem and switchgrass cultivars in a short growing season area. Agronomy Journal, 90(4), 489-495.

McKendry, P. (2002). Energy production from biomass (part 1): overview of biomass. Bioresource Technology, 83(1), 37-46. http://dx.doi.org/10.1016/S0960-8524(01)00118-3

McLaughlin, S. B., \& Kszos, L. A. (2005). Development of switchgrass (Panicum virgatum L.) as a bioenergy feedstock in the United States. Biomass and Bioenergy, 28, 515-535.

McLaughlin, S. B., Bouton, J., Bransby, D., Conger, B. V., Ocumpaugh, W. R., Parrish, D. J., ... Wullschleger, S. D. (1999). Developing switchgrass as a bioenergy crop. In J. Janick (Ed.), Perspectives on New Crops and New Uses (pp. 282-299). ASHS Press, Alexandria.

Monti, A., Venturi, P., \& Elbersen, H. W. (2001). Evaluation of the establishment of lowland and upland switchgrass (Panicum virgatum L.) varieties under different tillage and seedbed conditions in northern Italy. Soil and Tillage Research, 63(1-2), 75-83. http://dx.doi.org/10.1016/S0167-1987(01)00238-0

Piscioneri, L., Pignatelli, V., Palazzo, S., \& Sharma, N. (2001). Switchgrass production and establishment in the Southern Italy climatic conditions. Energy Conversion and Management, 42(18), 2071-2082. http://dx.doi.org/10.1016/S0196-8904(00)00174-6

Sanderson, M. A., \& Wolf, D. D. (1995). Morphological development of switchgrass in diverse environments. Agronomy Journal, 87(5), 908-915.

Schmer, M. R., Vogel, K. P., Mitchell, R. B., \& Perrin, R. K. (2008). Net energy of cellulosic ethanol from switchgrass, PNAS, 105(2), 464-469.

Schmer, M. R., Vogel, K. P., Mitchell, R. B., Moser, L. E., Eskridge, K. M., \& Perrin, R. K. (2006). Establishment stand thresholds for switchgrass grown as a bioenergy crop. Crop Science, 46, 157-161.

Skinner, R. H., \& Adler, P. R. (2010). Carbon dioxide and water fluxes from switchgrass managed for bioenergy

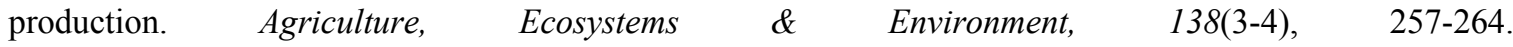
http://dx.doi.org/10.1016/j.agee.2010.05.008

Sladden, S. S., Bransby, D. I., \& Aiken, G. E. (1991). Biomass yield, composition and production costs for eight switchgrass varieties in Alabama. Biomass and Bioenergy, 1(2), 119-122. http://dx.doi.org/10.1016/0961-9534(91)90034-A

Smeets, E. M. W., Lewandowski, I. M., \& Faaij, A. P. C. (2009). The economical and environmental performance of miscanthus and switchgrass production and supply chains in a European setting. Renewable and Sustainable Energy Review, 13(6-7), 1230-1245. http://dx.doi.org/10.1016/j.rser.2008.09.006

Tolbert, V. R., Todd, D. E., Mann, L. K., Jawdy, C. M., Mays, D. A., \& Malik, R. (2002). Changes in soil quality and below-ground carbon storage with conversion of traditional agricultural crop lands to bioenergy crop production. Environmental Pollution, 116(1), S97-S106. http://dx.doi.org/10.1016/S0269-7491(01)00262-7

Tolbert, V. R., \& Wright, L. L. (1998). Environmental enhancement of US biomass crop technologies: research results to date. Biomass and Bioenergy, 15(1), 93-100. http://dx.doi.org/10.1016/S0961-9534(98)00005-1

USDA (Soil Survey Staff). (1975). Soil taxonomy. Basic system of soil classification for making and interpreting soil surveys. Agricultural Handbook, 466. USDA, Washington, DC.

Vaughan, D. H., Cundiff, J. S., \& Parrish, D. J. (1989). Herbaceous crops on marginal sites-Erosion and economics. Biomass, 20(3-4), 199-208. http://dx.doi.org/10.1016/0144-4565(89)90060-7

Venturi, P., \& Venturi, G. (2003). Analysis of energy comparison for crops in European agricultural systems. Biomass and Bioenergy, 25(3), 235-255. http://dx.doi.org/10.1016/S0961-9534(03)00015-1

\section{Copyrights}

Copyright for this article is retained by the author(s), with first publication rights granted to the journal.

This is an open-access article distributed under the terms and conditions of the Creative Commons Attribution license (http://creativecommons.org/licenses/by/3.0/). 